\title{
KILLER YEASTS INHIBIT THE GROWTH OF THE PHYTOPATHOGEN MONILIOPHTHORA PERNICIOSA, THE CAUSAL AGENT OF WITCHES' BROOM DISEASE
}

\author{
Anderson de Souza Cabral ${ }^{1}$; Patricia Maria Barroso de Carvalho ${ }^{1}$; Tatiana Pinotti ${ }^{2}$; Allen Norton Hagler ${ }^{1,2}$; \\ Leda Cristina Santana Mendonça-Hagler ${ }^{1,2}$; Andrew Macrae ${ }^{1,2 *}$
}

${ }^{1}$ Programa de Pós-Graduação em Biotecnologia Vegetal, Universidade Federal do Rio de Janeiro, Rio de Janeiro, RJ, Brasil;

${ }^{2}$ Instituto de Microbiologia Professor Paulo, Góes, Universidade Federal do Rio de Janeiro, Rio de Janeiro, RJ, Brasil.

Submitted: March 17, 2008; Returned to authors for corrections: April 30, 2008; Approved: February 17, 2009.

\section{SHORT COMMUNICATION}

\begin{abstract}
Fruit and soil yeasts isolated from the Amazon, Atlantic Rainforests and an organic farm were screened for killer activity against yeasts. Killer yeasts were then tested against the phytopathogen Moniliophthora perniciosa (syn. Crinipellis perniciosa) and a Dipodascus capitatus strain and a Candida sp strain inhibited its growth.
\end{abstract}

Key words: biocontrol, killer yeast, Witches' Broom, Moniliophthora perniciosa, Crinipellis perniciosa.

\section{MANUSCRIPT}

Yeasts are often associated with leaves, fresh and rotten fruits and flowers. They are also found in soils, sediments, water as well as on the external surfaces and intestinal tracts of animals, especially insects (5). Soils can be seen as reservoirs for mycocinogenic yeasts, insects can be seen as vectors and fruit pulps and plant surfaces as sites where yeasts compete, some using mycocins. The production of mycocinogenic toxins during secondary metabolism gives rise to a variety of killer phenomena. These phenomena are strain specific and appear to be involved in ecological strategies to exclude other microorganisms from carbon resources $(1,6)$. The killer phenotype is detected in Petri dishes by a distinctive halo of growth inhibition around colonies of a killer strain when they are grown against a background of sensitive cells. Some killer toxins can be active against a variety of phylogenetically distant yeasts strains. Interactions between killer yeasts and pathogenic fungi have also been described, indicating that killer yeasts toxins may have potential as antimicotic biocontrol agents $(9,13)$.

Using mycocinogenic / killer yeasts to manage biological processes has been recognized as important since 1963 (10). Since then, their use has been principally in the food and fermentation industries (11). The role of mycocinogenic yeasts in agricultural biotechnology as biocontrol agents is only now beginning to be exploited. This change is in part being driven by a desire for more sustainable alternatives to chemical pesticides. Bioprospection for yeasts as biocontrol agents has recently resulted in their employment in post-harvest protection of fruit from moulds (12). The role of killer yeasts in biocontrol strategies of other plant pathogens has, however, not been adequately explored nor developed.

Witches' Broom was first described in 1785. More than 100 years passed before its first scientific investigation in Suriname in 1895, on the basis of which the pathogen was identified (8). Moniliophthora perniciosa (formerly Crinipellis perniciosa), causal agent of Witches' Broom disease, has devastated cocoa (Theobroma cacao) production in Brazil and impoverished thousands involved in its production; the same story for cocoa is repeated globally throughout the tropics (2). Traditional methods to deal with the Witches' Broom disease have included: the removal and burning of diseased plant parts, using chemical fungicides and pre-selecting plants which show some resistance to the fungi (8). Recently, applying mixes of bacteria and fungi (particularly Trichoderma spp.) as biocontrol agents has led to some success at controlling the disease; however, there have

*Corresponding Author. Mailing address: Instituto de Microbiologia Professor Paulo, Góes, Universidade Federal do Rio de Janeiro UFRJ, Rio de Janeiro, RJ, Brasil. Cep: 21949-900. Tel.: 5521 2562-6739. E-mail: amacrae@biologia.ufrj.br 
been no reports of using yeasts in this role. Current best practice for disease management uses integrated approaches combining mixes of fungi and bacteria with chemical fungicides (3). Witches' Broom, however, continues to be a severe problem and the need to identify new biocontrol agents and to develop better technologies to combat $M$. perniciosa remains. Here we can now report on novel, widespread and diverse killer yeast activity and the discovery of yeast strains capable of inhibiting the growth of $M$. perniciosa "in vitro".

Bioprospection for killer activity involved a screening of 155 strains currently maintained within the yeast collection of the Instituto de Microbiologia Professor Paulo Góes, IMPPG-UFRJ. Strains originally isolated from Atlantic Rainforest soil, Amazon Rainforest soil (13), decomposing Jack-Fruit (Artocarpus heterophyllus) and from organic farm soil, SIPDA Embrapa Agrobiologia, Rio de Janeiro, were tested against a panel composed of 7 phylogenetically diverse yeasts. Potential killer strains as well as potential sensitive strains were grown on YM agar media (yeast extract, $0.3 \%$; malt extract, $0.3 \%$; peptone, $0.5 \%$; glucose, $1.0 \%$ and agar $2.0 \%$ ) with $0.003 \%$ of methylene blue, buffered at $\mathrm{pH} 4.2$ with a $0.06 \mathrm{M}$ citrate buffer. The following type strains: Candida tropicalis (ATCC $750^{\mathrm{T}}$ ), Clavispora lusitaniae (UCD 61-4 ${ }^{\mathrm{T}}$ ), Metschnikowia lunata (UCD 77-62 $)$, Crypococcus laurentii (NRRL Y-2536 ${ }^{\mathrm{T}}$ ) and Rhodotorula mucilaginosa (NRRL $\mathrm{Y}-2510^{\mathrm{T}}$ ) and authentic strains Candida glabrata (UWO Canada Y-55), Candida parapsilosis (51913 IMPPG/UFRJ) and Torulaspora delbrueckii (UCD 72-50) were spread to form an even lawn on the media, in Petri dishes, while potential killer strains were inoculated on top of the lawn using the replica plate method of Yarrow (15). Petri dishes were then incubated for 48 to 72 hours at $26^{\circ} \mathrm{C}$. Yeast strains were classified as killers when they produced an inhibition zone / halo without cellular growth and a blue zone of cellular death adjacent to this. When the halo was evident but the blue zone of cellular death was not, then yeasts were considered antagonists and were not classified as killers. Killer yeast strains identities were confirmed using standard methods (15) and by sequencing the D1 D2 region of 26S rRNA gene (4).

Killer yeasts were then confronted with a M. perniciosa strain isolated from infected cocoa plants showing witches' broom symptoms from Ilhéus, Bahia. This strain was identified as $M$. perniciosa on the basis of cultural characteristics and the morphology of fruiting bodies and spores. Fungal spores were suspended in sterile water and spread on the centre of potatodextrose-agar (PDA), in Petri dishes. The PDA was buffered at $\mathrm{pH} 4.4$ with a citrate buffer $(0.06 \mathrm{M})$ and incubated at $26^{\circ} \mathrm{C}$ until growth reached $4 \mathrm{~cm}$ in diameter. Killer strains were then inoculated, evenly spaced around the central fungal growth and incubated at $26^{\circ} \mathrm{C}$ for 10 days. Tests were done in duplicates on three separate occasions. Growth inhibition of $M$. perniciosa, when evident, was in the form of halos around the killer yeast (13). In all other cases $M$. perniciosa grew rapidly on the PDA covering both the media and yeast.
Of the 155 yeast strains investigated, 15 strains belonging to 8 different species met the criteria to be classified as killers. Of the 15, Candida sp. (51928 IMPPG/UFRJ) isolated from the organic farm soil, killed the following very diverse range of yeast species: C. glabrata, C. tropicalis, C. laurentii, T. delbrueckii, M. lunata and R. mucilaginosa. This Candida strain is an anamorph of Pichia sp. currently undergoing characterization to be described as a new species. A Dipodascus capitatus strain (51914 IMPPG/UFRJ) isolated from Jack Fruit killed the following yeast species: M. lunata, C. laurentii and $C$. Iusitaniae. These two killer strains repeatedly inhibited the growth of M. pernicious. This is the first report of a strain of the genus Dipodascus demonstrating killer activity against yeasts. These results are also the first known reports of yeast strains inhibiting the growth of $M$. perniciosa.

Bioprospection for novel biocontrol agents and the application of bioactive compounds offers accessible and sustainable alternatives to the use of conventional chemical methods for plant disease management. The discovery of yeast strains capable of inhibiting the growth of $M$. perniciosa highlights the continuing need to screen existing microbial culture collections for Agbiotech purposes. Given the relatively low cost and the vast and essentially untouched biotechnological potential of the microbial world, the value of maintaining and expanding diverse microbial collections is highlighted. Pichia and its anamorphs warrant special investigation as this genus is frequently cited in studies on killer yeast and their role in postharvest strategies to control rots and moulds is now being reported (9). To discover killer activity from a $D$. capitatus strain was a pleasant surprise. The discoveries reported here are timely reminders not to forget the potential role of yeasts in Agbiotech and, perhaps more importantly, that if we look we are likely to make important discoveries in our own backyards / culture collections.

\section{RESUMO}

\section{Leveduras micocinogênicas inibem o crescimento do fitopatógeno Moniliophthora perniciosa, o agente causador da doença Vassoura-de-bruxa}

Leveduras de frutas e de solo isoladas da Floresta Amazônica, Mata Atlântica e de uma fazenda orgânica foram selecionadas em uma triagem para atividade micocinogênica. As estirpes micocinogênicas foram posteriormente testadas frente a Moniliophthora perniciosa (syn. Crinipellis perniciosa). Uma estirpe de Dipodascus capitatus e outra de Candida sp. inibiram o crescimento deste fitopatógeno.

Palavras chave: biocontrole, leveduras micocinogênicas, vassoura-de-bruxa, Moniliophthora perniciosa, Crinipellis perniciosa 


\section{REFERENCES}

1. Abranches, J.; Valente, P.; Nóbrega, H.N.; Fernandez, F.A.S.; Mendonça-Hagler, L.C.; Hagler, A.N. (1998). Yeast diversity and killer activity dispersed in fecal pellets from marsupials and rodents in a Brazilian tropical habitat mosaic.FEMS Microb. Ecol., 26: 2733.

2. Dalla Pria, M.; Camargo, L.E.A. (1997). Doenças do Cacaueiro Manual de Fitopatologia, v. 2. Editora Agronômica Ceres Ltda. São Paulo, 178p.

3. Elad Y. (2003). Biocontrol of foliar pathogens: mechanisms and application. Commun. Agric. Appl. Biol. Sci. 68(4 Pt A): 17-24.

4. Kurtzman, C.P.; Robnett, C.J. (1998). Identification and phylogeny of ascomycetous yeasts from analysis of nuclear large subunit (26S) ribosomal DNA partial sequences. Antonie van Leeuwenhoek. C.J. Anton. van Leeuwen., 73: 331-371.

5. Lachance, M.A.; Starmer, W.T. (1998). Ecology and Yeasts. In: Kurtzman, C.P.; Fell, W.F. (eds). The Yeast, a Taxonomic Study, $4^{\text {th }}$ ed. Elsevier, Amsterdam, p. 21-30.

6. Morais, P.B.; Martins, M.B.; Klaczko, L.B.; Mendonça-Hagler, L.C.; Hagler, A.N. (1995). Yeast succession in the Amazon fruit Parahancornia amapa as resource partitioning among Drosophila spp. Appl. Environ. Microbiol., 61(12): 4251-4257.

7. Purdy, L.H.; Schmidt R.A. (1996). Status of cacao witches' broom: biology, epidemiology, and management. Ann. Rev. Phytopathology, 34: 573-594, 1996.
8. Richards, G.M.; Buck, J.W.; Beuchat, L.R. (2004). J. Food Prot., 67(10): 2132-2142.

9. Soares, G.A.M; Sato, H.H. (2000). Chraracterization of the Saccharomyces cerevisiae Y500-4L killer toxin. Braz. J. Microbiol., 31: 291-297.

10. Schimitt, M.J.; Breinig, F. (2002). The viral killer system in yeast: from molecular biology to application. FEMS Microb. Rev., 26: 257-276.

11. Seki, T.; Choi, E.W.; Ryu, D. (1985). Construction of killer wine yeast strain. Appl. Environ. Microbio, 49: 1211-1215.

12. Spots, R.A.; Cervantes, L.A.; Facteau, T.J. (2002). Integrated control of brown rot of sweet cherry fruit with a preharvest fungicide, a postharvest yeast, modified atmosphere packaging, and cold storage temperature. Postharvest Biol. Technol., 24(3): 251-257.

13. Vital, M.J.S.; Abranches, J.; Hagler, A.N.; Mendonça-Hagler, L.C. (2002). Mycocinogenic yeasts isolated from Amazon soils of the Maracá ecological station, Roraima-Brazil. Braz. J. Microbiol., 33: 230-235.

14. Walker, G.M.; McLeod, A.H.; Hodgson, V.J. (1995). Interactions between killer yeasts and pathogenic fungi. FEMS Microb. Lett., 127: 213-222.

15. Yarrow, D. (1998). Methods for the isolation and Identification of Yeasts. in: Kurtzman, C.P.; Fell, J.W. The Yeasts, a taxonomic study. 4th ed. Elsevier, Amsterdan, p.77-100. 